Studia nad Autorytaryzmem i Totalitaryzmem 43, nr 3 Wrocław 2021

https://doi.org/10.19195/2300-7249.43.3.9

\author{
ARTUR OGUREK \\ ORCID: 0000-0001-9073-6262 \\ Uniwersytet Wrocławski \\ artur.ogurek@uwr.edu.pl
}

\title{
Pozycja prawna pracowników kolejowych w okresie militaryzacji PKP w drugiej połowie lat czterdziestych XX wieku
}

\author{
Slowa kluczowe: demilitaryzacja militaryzacja, Polskie Koleje Państwowe (PKP), Wojskowa \\ Prokuratura PKP, Wojskowy Sąd PKP

\section{LEGAL STATUS OF RAILWAY WORKERS IN THE PERIOD OF THE MILITARIZATION OF RAILWAYS IN POLAND IN THE SECOND HALF OF THE 40S \\ OF THE XX CENTURY}

\begin{abstract}
The article is an attempt to present the changes in legal status of railway workers as a result of the militarization of railways in Poland in the second half of the 1940s, including the context and consequences of the militarization process. Literature research as well as query and analysis of legal acts led us to the conclusion that as a result of recognizing PKP employees as called up for military service, their subordination for committed crimes, the jurisdiction of the Military Prosecutor's Office of the Polish State Railways, and the Military Court of PKP were established.

In the article I also describe the main factors of the transformation the special justice system underwent in the analyzed period, proving that it was not the first militarization of the railways in Poland, as well as that the legal acts introducing the militarization in 1944 referred to - at least partially - the tradition of the previous double militarization of railways in the Second Polish Republic.
\end{abstract}

Keywords: demilitarization, militarization, Polish State Railways (PKP), Military Prosecutor's Office PKP, Military Court of PKP 


\section{Wprowadzenie - przesłanki polityczno-gospodarcze militaryzacji PKP}

Od początku wyzwalania pierwszych regionów Polski spod niemieckiej okupacji w roku 1944 przed władzą „ludową” zaczęły piętrzyć się istotne zadania do wykonania, wśród nich przede wszystkim odbudowa kraju ze zniszczeń wojennych, do czego niezbędne było uruchomienie transportu kolejowego - jedynego zdolnego podołać ogromnej pracy przewozowej. Ze względu na konieczność terminowych przewozów ładunków wojennych kolej była najważniejszą formą transportu, o podstawowym znaczeniu wojskowym ${ }^{1}$, w związku z czym usilnie starano się, aby wszelkie działania sił opozycyjnych, często sabotujących transport kolejowy, nie zagroziły interesom odradzającego się państwa ${ }^{2}$.

Stan linii kolejowych na ziemiach polskich pod koniec wojny, a także tuż po jej zakończeniu, był fatalny. Eksploatację utrudniały brak taboru, urządzeń technicznych oraz sygnalizacyjnych ${ }^{3}$.

Skala zniszczeń wynikała już choćby z tego, że od początku wojny głównym celem wojsk niemieckich było zniszczenie sieci komunikacyjnej, aby uniemożliwić w ten sposób przerzut wojsk oraz ewakuację. We wrześniu 1939 roku koleje poniosły bardzo duże straty, bo ważniejsze węzły kolejowe były bombardowane nawet kilka razy dziennie, w efekcie czego prawie całkowicie zniszczona została infrastruktura kolejowa ważniejszych węzłów i tras ${ }^{4}$.

Zniszczenia to także efekt wielu późniejszych działań sabotażowych i dywersyjnych podziemia zbrojnego, które atakowało kolej, utrudniając w ten sposób nie tylko transport materiałów wojennych i żołnierzy oraz funkcjonowanie okupacyjnej gospodarki, lecz także przewóz więźniów do obozów koncentracyjnych i miejsc zagłady ${ }^{5}$. W końcowym okresie wojny wycofujący się Niemcy zabierali niemal cały zdatny do użytku tabor kolejowy. Wyzwalane tereny albo były go pozbawione, albo stan techniczny taboru był bardzo zły ${ }^{6}$. Ogółem straty wojenne w kolejnictwie poniesione przez Polskę w drugiej wojnie światowej wyniosły ponad $16 \mathrm{mld} \mathrm{zt}^{7}$.

${ }^{1}$ E. Romanowska, Wojskowe Prokuratury Polskich Kolei Państwowych w latach 1944-1949 - formalno-prawne podstawy działalności, „Przegląd Historyczno-Wojskowy” 12, 2011, nr 1 (234), s. 109. Także J. Jarosiński, Wspótpraca sądu i prokuratury wojskowej ze Zwiąkiem Zawodowym Pracowników Kolejowych w latach 1944-1949, „Wojskowy Przegląd Prawniczy” 1982, nr 1, s. 67 n.

2 E. Romanowska, Karzace ramię sprawiedliwości ludowej. Prokuratury wojskowe w Polsce w latach 1944-1955, Warszawa 2012, s. 193.

3 J. Prokopowicz, Rola Prokuratury Wojskowej PKP w zakresie uruchomienia i usprawnienia kolejnictwa, „Wojskowy Przegląd Prawniczy” 1945, nr 3, s. 173.

4 S. Zamkowska, Odbudowa i funkcjonowanie kolei polskich 1944-1949, Warszawa 1984, s. 21.

5 Dzieje kolei w Polsce, red. D. Keller, Rybnik 2012, s. 43.

6 S. Zamkowska, op. cit., s. 26.

7 Ibidem, s. 39. 
Zważywszy na ogrom zadań przewozowych i skalę strat i zniszczeń, a także stan taboru, konieczne stało się sprawne wykorzystanie ograniczonych zasobów. Aby wykonywanie zadań było skoordynowane, a dyscyplina pracy zachowana, postanowiono wprowadzić środki nadzwyczajne. Naczelne kierownictwo państwa zdecydowało o potrzebie militaryzacji kolei. Wprowadzono ją na mocy dekretu Polskiego Komitetu Wyzwolenia Narodowego z 4 listopada 1944 roku o militaryzacji Polskich Kolei Państwowych ${ }^{8}$, wydanego na podstawie ustawy z 15 sierpnia 1944 roku o tymczasowym trybie wydawania dekretów z mocą ustawy ${ }^{9}$. Dekret ów zastąpił ustawę z 30 marca 1939 roku o komunikacjach w służbie obrony Państwa ${ }^{10}$ i stanowił, że na czas wojny Polskie Koleje Państwowe podlegają militaryzacji, a — jako podległe Naczelnemu Dowódcy WP — mogą zostać użyte, w całości lub w części, do zadań natury wojskowej, zatrudnione zaś w tym przedsiębiorstwie osoby uznano za zmobilizowane do służby wojskowej w komunikacji kolejowej.

Za militaryzacją kolei przemawiały oczywiście i czynniki polityczne, nie tylko wewnętrzne, ale i zewnętrzne (międzynarodowe). Podstawowym warunkiem przejęcia pełni władzy w Polsce w latach 1944-1945 przez środowiska proradzieckie miało być między innymi jak najszybsze zlikwidowanie wszelkiej opozycji politycznej. Jednak gdy opór sporej części ludności cywilnej wspierał działania londyńskiego rządu emigracyjnego i opozycyjnych ugrupowań w kraju, nowa władza zadecydowała o możliwości użycia nadzwyczajnych środków zalegalizowania państwowej przemocy. Za najlepszy sposób ugruntowania takich form działania uznano między innymi represyjną działalność prokuratur i sądów, które legitymizowałyby działania władz. Wymagało to jednak dokonania przeobrażeń organizacyjno-legislacyjnych istniejącego dotąd wymiaru sprawiedliwości w taki sposób, aby ferowane wyroki mogły stać się faktycznym narzędziem represji państwa ${ }^{11}$.

Narzędziem tej swoistej wojny dla „,nowych” władz, choć nie w pełni suwerennych i coraz bardziej uzależnionych od wielkiego wschodniego sąsiada, stał się wymiar sprawiedliwości - gruntownie „odnowiony” i upolityczniony, głęboko oddany władzy „ludowej”12. W Polsce po roku 1944 sądownictwo i prokuratury

${ }^{8}$ Dekret PKWN z 4 listopada 1944 r. o militaryzacji Polskich Kolei Państwowych, Dz.U. R.P. $1944 \mathrm{nr}$ 11, poz. 55.

9 Ustawa z 15 sierpnia 1944 r. o tymczasowym trybie wydawania dekretów z mocą ustawy, Dz.U. R.P. 1944 nr 1, poz. 3.

10 Ustawa z 30 marca 1939 r. o komunikacjach w służbie obrony Państwa, Dz.U. R.P. 1939 nr 29, poz. 195. Ustawa ta przewidywała — na wypadek wojny — militaryzację nie tylko kolei żelaznych, ale też poczt, telegrafów i telefonów, żeglugi morskiej, śródlądowej i powietrznej oraz dróg i ruchu kołowego.

11 Więcej na ten temat S. Żurawicki, Tendencje prawodawcze demokracji ludowej, „Wojskowy Przegląd Prawniczy” 1946, nr 2-3, s. 118. Także A. Rzepliński, Przystosowanie ustroju sądownictwa do potrzeb państwa totalitarnego w Polsce w latach 1944-1956, [w:] Przestępstwa sędziów i prokuratorów w Polsce lat 1944-1956, red. W. Kulesza, A. Rzepliński, Warszawa 2000, s. 9.

12 Więcej w pracy K. Jasiak, W majestacie ,, ludowego prawa”. Skazani przez ,wymiar sprawiedliwości” w Lodzi w latach 1945-1956, „Kultura i Historia” 2004, nr 7. 
stały się bowiem de facto jedną z form jednolitej władzy państwowej, wyodrębnioną tylko organizacyjnie ${ }^{13}$, a duża grupa cywilnych obywateli została jej poddana.

$\mathrm{Z}$ perspektywy czasu należałoby uznać, że w istocie militaryzacja PKP, choć politycznie różnie oceniana, pozwoliła na lepsze wykorzystanie transportu kolejowego nie tylko w bieżącym zaopatrywaniu wojsk, wciąż walczących na froncie, ale i w późniejszej odbudowie kraju ${ }^{14}$.

Militaryzacja kolei w 1944 roku nie była pierwszą w Polsce. Mimo że wprowadzając ją, powoływano się na doświadczenia militaryzacji kolei w ZSRR w roku 1944, które miały służyć za przykład (wzór?) tego, jakie efekty ${ }^{15}$ można osiągnąć w Polsce, to przecież także i polskie doświadczenia minionych lat mogły być pomocne w realizacji złożeń i celów stawianych przed PKP u schyłku drugiej wojny światowej. W okresie II Rzeczypospolitej mieliśmy bowiem do czynienia z dwukrotną militaryzacją kolei na terenie całego państwa w czasie działań wojennych w roku 1920 (gdy nierozstrzygnięte były losy zarówno wschodniej, jak i zachodniej granicy dopiero kształtującego się państwa polskiego) oraz w roku 1939, gdy coraz wyraźniej zbliżało się zagrożenie wybuchem konfliktu polsko-niemieckiego.

Zasady funkcjonowania kolei w warunkach jej militaryzacji w 1920 roku regulowała ustawa z dnia 27 marca 1920 roku o kolejach w czasie wojny ${ }^{16}$. Na jej mocy na czas wojny wszystkie koleje żelazne podporządkowywano interesom obrony państwa. Władze kolei państwowych i prywatnych zobowiązane były do ścisłego współdziałania z władzami wojskowymi także w czasie pokoju i udziału w pracach przygotowawczych, mających na celu utrzymanie sprawności kolei w okresie działań wojennych. $Z$ dniem ogłoszenia mobilizacji prywatne przedsiębiorstwa kolei żelaznych miały przechodzić pod zarząd Ministerstwa Kolei, a ich władze kolejowe stawały się organami wykonawczymi ministerstwa.

Większą skalę miała militaryzacja, jakiej dokonano w 1939 roku, przed wybuchem drugiej wojny światowej. Na mocy ustawy z 30 marca 1939 roku o komunikacji w służbie obrony państwa ${ }^{17}$ władze i organa rządowe oraz państwowych przedsiębiorstw komunikacyjnych, w tym PKP, zostały zobowiązane już w czasie pokoju do ścisłego współdziałania z władzami wojskowymi i udziału w pracach przygotowawczych, mających na celu zapewnienie sprawności transportu kolejowego w interesie obrony państwa. Minister Spraw Wojskowych, w porozumieniu z właściwymi ministrami, w celu sprawdzenia stanu prac przygotowawczych, mógł - już w czasie pokoju — zarządzić, na obszarze całego

13 W. Tkaczew, Powstanie i działalność organów Informacji Wojska Polskiego w latach 19431948, Warszawa 1994, s. 207.

14 J. Nazarewicz, Działalność legislacyjna państwa ludowego w zakresie prawnej jego ochrony w latach 1944-1945, „Wojskowy Przegląd Prawniczy” 1979, nr 2, s. 136 n.

15 J. Dziowgo, $W$ walce z przestępczościa w kolejnictwie, „Wojskowy Przegląd Prawniczy” 1946, nr 1, s. 48.

${ }^{16}$ Ustawa z 27 marca 1920 r. o kolejach w czasie wojny, Dz.U. R.P. 1920 nr 27, poz. 160.

17 Ustawa z 30 marca 1939 r. o komunikacji w służbie obrony państwa, Dz.U. R.P. 1939 nr 29, poz. 195. 
państwa lub w poszczególnych jego częściach, kontrolę sprawności działania komunikacji. W razie wybuchu wojny lub zarządzenia mobilizacji, a także gdyby tego wymagał interes obrony państwa, stwierdzony uchwałą Rady Ministrów, należało podporządkować działalność PKP interesom obrony państwa. Rada Ministrów mogła też — z uwzględnieniem obowiązujących porozumień międzynarodowych - postanowić o wstrzymaniu lub ograniczeniu ruchu na wszystkich lub niektórych liniach komunikacyjnych.

\section{Wojskowy Sąd PKP i Wojskowa Prokuratura PKP w okresie militaryzacji kolei}

Rozbudowa specjalnego sądownictwa wojskowego i objęcie nim ludności cywilnej, w tym wypadku pracowników służby kolejowej, nastąpiło na podstawie dekretu PKWN z 4 listopada 1944 roku o militaryzacji Polskich Kolei Państwowych; na jego mocy, a także na podstawie pkt 4 rozkazu organizacyjnego $\mathrm{nr} 72 /$ org. ND WP z 25 listopada 1944 roku $^{18}$, wydanego również na podstawie treści dekretu PKWN Prawo o ustroju Sądów Wojskowych i Prokuratury Wojskowej z 23 września 1944 roku $^{19}$, formalnie powołano Wojskowy Sąd PKP i Wojskową Prokuraturę PKP ${ }^{20}$ jako pierwsze spośród wszystkich „specjalnych” sądów i prokuratur wojskowych.

W przytaczanym rozkazie nr 72/org., w pkt 5, Szef Sądownictwa Wojskowego nakazał, aby do 15 grudnia 1944 roku sformować nowy sąd ${ }^{21}$ oraz jego trzy ekspozytury przy dyrekcjach PKP. Pierwszą siedzibą tego sądu był Lublin, skąd - 14 lutego 1945 roku - przeniesiono go do Warszawy, gdzie urzędował w siedzibie DOKP ${ }^{22}$. Nieco wcześniej, bo jeszcze 30 listopada 1944 roku, na szefa tegoż sądu wyznaczono mjr. Aleksandra Tomaszewskiego ${ }^{23}$.

18 Rozkaz organizacyjny nr 72/Org. z dnia 25 listopada1944 r., za: J. Nazarewicz, Udziat Prokuratury wojskowej w ochronie ludowo-demokratycznego ustroju w Polsce w latach 1944-1955, „Wojskowy Przegląd Prawniczy” 1983, nr 3, s. 219.

19 Dekret PKWN z 23 września 1944 r. Prawo o ustroju Sądów Wojskowych i Prokuratury Wojskowej, Dz.U. R.P. 1944 nr 6, poz. 29.

20 Wojskowy Sąd PKP i Wojskową Prokuraturę sformowano na podstawie rozkazu NDWP nr 72/org. z 25 listopada 1944 r., a rozformowano rozkazem MON nr 0165/org. z 8 sierpnia 1949 r. Właściwości Sądu i Prokuratury określił rozkaz NDWP nr 130 z 2 grudnia 1944 r. Zob. A. Miętek, Materiały źródłowe obrazujące działalność sądów wojskowych Ludowego Wojska Polskiego w okresie wojny 1943-1945, „Biuletyn Wojskowej Służby Archiwalnej” 1971, nr 3. Także A. Wesołowski, $W$ cieniu wojny i polityki. Sądownictwo Wojska Polskiego na froncie wschodnim w latach 1943-1945, Toruń 2003, s. 195.

21 M. Zaborski, Ustrój sq̨dów wojskowych w Polsce w latach 1944-1955, Lublin 2005, s. 221.

22 R. Ostafiński-Bodler, Sady wojskowe w Polskich Siłach Zbrojnych i ich kompetencje w sprawach karnych 1914-2002, Toruń 2002, s. 269.

23 K. Szwagrzyk, Prawnicy czasu bezprawia. Sędziowie i prokuratorzy wojskowi w Polsce 1944-1956, Kraków-Wrocław 2005, s. 449. 
Równolegle do Wojskowego Sądu PKP powołano Wojskową Prokuraturę PKP oraz jej ekspozytury — w założeniu dla każdej samodzielnej dyrekcji okręgowej PKP ${ }^{24}$. Pierwszą siedzibą Wojskowej Prokuratury Polskich Kolei Państwowych był Lublin; prokuratura zajęła pomieszczenia przy ul. Wyszyńskiego i Szopena, zanim to jednak nastąpiło, działała, nie mając formalnie swojej siedziby. Wojskowy prokurator PKP mjr J. Prokopowicz urzędował w lokalu należącym do Naczelnej Prokuratury Wojska Polskiego. Wkrótce Wojskowa Prokuratura PKP została przeniesiona do Warszawy, przede wszystkim dzięki staraniom prokuratora J. Prokopowicza, który uważał, że ogrom pracy, jakim została obciążona, wymaga, aby jej siedziba znajdowała się w Warszawie, a w zamian za to w Lublinie miała działać tak jak przy innych DOKP ekspozytura tejże prokuratury. Prokurator J. Prokopowicz, w porozumieniu z ministrem komunikacji Janem Rabanowskim, postanowił w końcowych dniach lutego 1945 roku przenieść Wojskową Prokuraturę PKP z Lublina do siedziby Ministerstwa Komunikacji przy ul. Wileńskiej 4 w Warszawie, gdzie rozpoczęła urzędowanie od 1 marca 1945 roku $^{25}$.

Zapewnienie nadzoru prokuratorskiego nad odbudowywaną siecią PKP na wyzwolonych terenach kraju uzasadniało potrzebę powoływania kolejnych ekspozytur prokuratury przy DOKP: warszawskiej, łódzkiej, katowickiej, poznańskiej, gdańskiej (z siedzibą w Bydgoszczy), olsztyńskiej, krakowskiej i lubelskiej ${ }^{26}$. Powołano również ekspozytury przy DOKP we Wrocławiu i Szczecinie ${ }^{27}$. W ten sposób Wojskowa Prokuratura PKP uzyskała podstawę do działania na terenie niemal całej Rzeczypospolitej. Wrocławska ekspozytura prokuratury PKP została utworzona rozkazem Naczelnego Dowódcy WP z dnia 28 listopada 1946 roku nr 0216/org., Szefa Departamentu Służby Sprawiedliwości M.O.N. z 6 grudnia 1946 roku nr 01599/46/I oraz z 10 stycznia 1947 roku nr $01^{28}$.

24 E. Romanowska, Karzace ramie..., s. 193. Także A. Wesołowski, op. cit., s. 195.

25 IPN BU 894/86, Naczelna Prokuratura Wojskowa w Warszawie. Sprawozdanie WP PKP opisowe z działalności i statystyczne o przestępczości. Sprawozdanie opisowe z pracy Wojskowej Prokuratury PKP za miesiac luty 1945 r., s. 25.

26 IPN BU 894/86, Naczelna Prokuratura Wojskowa w Warszawie. Sprawozdanie WP PKP opisowe z działalności i statystyczne o przestępczości. Sprawozdanie opisowe z pracy Wojskowej Prokuratury PKP za miesiąc lipiec 1945 r., s. 240.

27 IPN BU 894/86, Naczelna Prokuratura Wojskowa w Warszawie. Sprawozdanie WP PKP — opisowe z działalności i statystyczne o przestępczości. Sprawozdanie opisowe z pracy Wojskowej Prokuratury PKP za miesiąc listopad 1945 r., s. 390.

28 IPN BU 807/653; 929/63/653, Naczelna Prokuratura Wojskowa w Warszawie. Sprawozdania statystyczne Ekspozytury PKP Wrocław. Sprawozdanie opisowe z pracy Ekspozytury Wojskowej Prokuratury PKP przy DOKP Wrocław za miesiąc styczeń 1947 r., s. 4. 


\section{Właściwość Wojskowego Sądu PKP i Wojskowej Prokuratury PKP a status pracowników kolejowych}

Właściwość miejscowa Wojskowej Prokuratury Polskich Kolei Państwowych oraz Wojskowego Sądu Polskich Kolei Państwowych, w rozumieniu art. 13 dekretu Prawo o ustroju Sądów Wojskowych i Prokuratury Wojskowej 23 września 1944 roku, to każdy obszar państwa polskiego, na którym znajdowały się obiekty kolejowe - urządzenia, warsztaty, stacje, składy PKP i miejsca pracy zatrudnionych na PKP ${ }^{29}$.

Do właściwości rzeczowej Wojskowej Prokuratury Polskich Kolei Państwowych oraz Wojskowego Sądu Polskich Kolei Państwowych należało rozpoznawanie spraw wszystkich funkcjonariuszy PKP o popełnione przez nich na służbie przestępstwa przewidziane $\mathrm{w}$ kodeksie karnym WP oraz $\mathrm{W}$ ustawach szczególnych, a zwłaszcza w ustawie z 30 marca 1939 roku o komunikacjach w służbie obrony Państwa ${ }^{30}$. Właściwość rzeczowa nie obejmowała jednak spraw przewidzianych w dekrecie PKWN z 30 października 1944 roku o ochronie Państwa oraz art. 85-99 i 101-103 kodeksu karnego WP. Postępowanie przygotowawcze w tych sprawach (czyli o napady na pociągi, niszczenie urządzeń kolejowych, zabójstwa pasażerów i personelu itp.), wszczynane przez prokuratury kolejowe, były przekazywane według właściwości wojskowym prokuraturom garnizonowym ${ }^{31}$.

Zmiany w zakresie właściwości rzeczowej Wojskowego Sądu PKP i Wojskowej Prokuratury PKP nastąpiły w styczniu 1946 roku, z chwilą powołania wojskowych sądów rejonowych (WSR) i wojskowych prokuratur rejonowych (WPR), podlegających bezpośrednio Najwyższemu Sądowi Wojskowemu i Naczelnej Prokuraturze Wojskowej ${ }^{32}$, których obszar działania pokrywał się najczęściej z obszarem województw ${ }^{33}$.

Organy te przejęly między innymi wszystkie sprawy funkcjonariuszy PKP; $\mathrm{z}$ tą chwilą zasadniczym zadaniem kolejowego wymiaru sprawiedliwości stało się zwalczanie przestępczości pospolitej wśród pracowników PKP, związanej z naruszeniem dyscypliny, zasad bezpieczeństwa czy przestępstwami przeciwko bezpieczeństwu ruchu ${ }^{34}$.

29 IPN BU 894/130 Naczelna Prokuratura Wojskowa w Warszawie. Rozkaz Naczelnego Dowództwa Wojska Polskiego nr 130 z 2 grudnia 1944 r.

30 R. Ostafiński-Bodler, op. cit., s. 332.

31 J. Nazarewicz, op. cit., s. 218 n.

32 A. Kochański, Polska 1944-1991. Informator historyczny, t. 1. Podzial administracyjny, ważniejsze akty prawne, decyzje i enuncjacje państwowe (1944-1956), Warszawa 1996, s. 124 n. Także aneks 2 w M. Zaborski, Oni skazywali na śmierć... Szkolenie sędziów wojskowych w Polsce w latach 1944-1956, [w:] Skryte oblicze systemu komunistycznego. U źródet zła, red. R. Bäcker, P. Hübner, Warszawa 1997, s. 142 n.

33 J. Nazarewicz, op. cit., s. 454.

34 E. Romanowska, Karzace ramię..., s. 197. 
Właściwość podmiotowa Wojskowego Sądu PKP i Wojskowej Prokuratury PKP, określona w art. 2 dekretu o militaryzacji Kolei Państwowych, dotyczyła wszystkich pracowników zatrudnionych w PKP, którzy uznawani byli za zmobilizowanych do służby wojskowej w komunikacji kolejowej ${ }^{35}$.

\section{Zmiana statusu prawnego pracowników kolejowych w następstwie militaryzacji PKP}

Militaryzacja kolei sprawiła, że pracownicy Polskich Kolei Państwowych zostali powołani do wojskowej służby w komunikacji kolejowej, zatem — de iure i de facto - stali się żołnierzami i w stosunku do nich miały odtąd zastosowanie wojskowe przepisy prawa. W wypadku użycia PKP do zadań wojskowych zarządzanie nimi oraz władza dyscyplinarna nad pracownikami kolejowymi przechodziły na Naczelnego Dowódcę WP lub na osoby przezeń upoważnione.

Zgodnie z dekretem z 4 listopada 1944 roku o militaryzacji Polskich Kolei Państwowych, na mocy art. 4 tegoż dekretu, działalność kolei podporządkowano władzom wojskowym, a pracownicy koleizmobilizowani do służby wojskowej w komunikacji kolejowej za przestępstwa popełnione na służbie, ale także za przestępstwa pospolite, mieli ponosić odpowiedzialność przed wojskowym wymiarem sprawiedliwości według przepisów kodeksu karnego Wojska Polskiego. Do rozpatrywania tych spraw właściwymi były sądy wojskowe, postępowanie przygotowawcze zaś prowadziły wojskowe organa ścigania ${ }^{36}$.

Podległość osób zatrudnionych na kolei pod wojskowy wymiar sprawiedliwości została potwierdzona postanowieniem Najwyższego Sądu Wojskowego z dnia 19 listopada 1945 roku, które za żołnierzy uważało również osoby zatrudnione w dziedzinach zmilitaryzowanych — na zasadzie stosunku publicznoprawnego lub umownego - stanowiły stałą obsadę osobową działu zmilitaryzowanego ${ }^{37}$.

Na mocy art. 5 dekretu czynności dochodzeniowo-śledcze i procesowe mogły wykonywać też organa powszechnego wymiaru sprawiedliwości, ale z zastrzeżeniem, że po ukończeniu postępowania karnego (dochodzenia lub śledztwa) musiały przekazać sprawę właściwemu wojskowemu organowi wymiaru sprawiedliwości, co wyraźnie potwierdzało podległość pracowników PKP wojskowemu wymiarowi sprawiedliwości ${ }^{38}$. Stanowisko to znajdowało pełne potwierdzenie w rozkazach Naczelnego Dowództwa Wojska Polskiego nr 130 z dnia 2 grudnia 1944 roku (pkt 3) o zaniechaniu mobilizacji funkcjonariuszy PKP do regularnych oddziałów wojskowych oraz nr 142 z dnia 18 grudnia 1944 roku o wprowadzeniu

\footnotetext{
35 R. Ostafiński-Bodler, op. cit., s. 332.

36 J. Nazarewicz, op. cit., s. 218.

37 „Wojskowy Przegląd Prawniczy” 2, 1946, nr 1, s. 62.

38 E. Romanowska, Wojskowe Prokuratury..., s. 111.
} 
w PKP wojskowych przepisów dyscyplinarnych ${ }^{39}$. Osoby pracujące na kolei nie były zatem mobilizowane do służby w regularnych oddziałach wojskowych, ponieważ praca na kolei traktowana była równoważnie ze służbą $\mathrm{w}$ jednostkach bojowych $^{40}$.

W kontekście właściwości podmiotowej Sądu i Prokuratury Wojskowej PKP istotne wydaje się zatem zadanie pytań: kto $\mathrm{w}$ istocie był kolejarzem oraz czy wszyscy zatrudnieni na kolei byli kolejarzami? Odpowiedź na nie miała bowiem zadecydować o tym, czy dany podmiot podlegać będzie wojskowemu czy też powszechnemu wymiarowi sprawiedliwości.

Pozycję prawną zatrudnionych na kolei, jak też status prawny kolejarzy określało kilka aktów prawnych. Pierwszym aktem, który regulował pozycję prawną osób zatrudnionych na kolei, stało się rozporządzenie Rady Ministrów z 1 stycznia 1934 roku o stosunku służbowym pracowników przedsiębiorstwa Polskie Koleje Państwowe ${ }^{41}$, które obowiązywało aż do 12 sierpnia 1945 roku, a więc w czasie gdy kolej była już zmilitaryzowana.

Postanowienia dotyczące pozycji prawnej podmiotów zatrudnionych na kolei były regulowane w części pierwszej wspomnianego rozporządzenia. Na mocy zawartych tam postanowień rozróżniono pracowników: mianowanych na stanowiska etatowe, zwanych pracownikami etatowymi; pracowników stałych — wykonujących stałe zajęcia służbowe; osoby odbywające służbę przygotowawczą na stanowiska etatowe i służbowe, zwane praktykantami. Wymienione osoby otrzymały status pracowników PKP. Dopełnieniem tych wymagań był art. 7 rozporządzenia, który formułował obostrzenia odnośnie do tego, kto nie mógł zostać pracownikiem PKP. Pracownikiem PKP nie mogła zostać: osoba skazana wyrokiem sądu karnego na dodatkową karę utraty praw publicznych; osoba skazana wyrokiem sądu karnego za przestępstwa popełnione z chęci zysku lub innych niskich pobudek; osoba wydalona ze służby kolejowej lub innej służby państwowej albo ze służby samorządowej; osoba, przeciw której się toczyło postępowanie karno-sądowe za przestępstwa popełnione $\mathrm{z}$ chęci zysku lub z innych niskich pobudek, postępowanie upadłościowe lub postępowanie o pozbawienie własnej woli (w czasie trwania postępowania nie mogła zostać mianowana pracownikiem PKP).

Rozporządzenie z 1934 roku zostało zastąpione nowym aktem prawnym, a mianowicie rozporządzeniem Rady Ministrów z 2 listopada 1945 roku o służbie w przedsiębiorstwie „Polskie Koleje Państwowe” 42 , które — po części — właściwie powielało postanowienia rozporządzenia z 1934 roku.

39 R. Ostafiński-Bodler, op. cit., s. 285.

40 IPN BU 894/130, Naczelna Prokuratura Wojskowa w Warszawie, Rozkazy personalne władz zwierzchnich. Etat OSW/8, k. 63.

41 Rozporządzenie Rady Ministrów z 1 stycznia 1934 r. o stosunku służbowym pracowników przedsiębiorstwa „Polskie Koleje Państwowe”, Dz.U. R.P. 1934 nr 4, poz. 23.

42 Rozporządzenie Rady Ministrów z 2 listopada 1945 r. o służbie w przedsiębiorstwie „Polskie Koleje Państwowe”, Dz.U. R.P. 1945 nr 52, poz. 299. 
Szczególnie ważną rolę w określaniu grupy pracowników kolei, podległych wojskowej prokuraturze PKP, odegrało też rozporządzenie Ministra Obrony Narodowej z 22 marca 1945 roku o powołaniu do wojskowej służby komunikacji na kolejach $^{43}$, wydane w porozumieniu z ministrami: Komunikacji, Bezpieczeństwa Publicznego i Sprawiedliwości, uzupełnione następnie rozporządzeniem wykonawczym Ministra Komunikacji o powołaniu do wojskowej służby komunikacji na kolejach. To dzięki niemu militaryzacja kolei została utrzymana mimo formalnego zniesienia stanu wojennego.

$\mathrm{Na}$ mocy tego rozporządzenia powołani do wojskowej służby komunikacji na kolejach zostali wszyscy obywatele państwa polskiego, bez względu na płeć, którzy nie ukończyli 60 roku życia, choćby nie podlegali powszechnemu obowiązkowi wojskowemu, a którzy: w jakimkolwiek czasie byli funkcjonariuszami lub pracownikami Polskich Kolei Państwowych albo kolei prywatnych w Polsce ${ }^{44}$; w czasie okupacji Polski byli funkcjonariuszami lub pracownikami Kolei Wschodniej lub niemieckich kolei państwowych lub prywatnych ${ }^{45}$; mieli fachową praktykę lub wykształcenie w dziedzinie komunikacji kolejowej ${ }^{46}$. Osoby takie zobowiązane zostały do tego, by zarejestrować się na najbliższej stacji kolejowej, po zarejestrowaniu zaś i po wezwaniu władz — zgłosić się do czynnej służby w polskich kolejach państwowych. W wypadku uchylania się od pracy w przedsiębiorstwie PKP, miały podlegać odpowiedzialności karnej, w myśl przepisów kodeksu karnego WP.

Katalog osób podległych prokuraturze kolejowej był - pozornie - jasno określony i tworzyli go wymienieni pracownicy, a mianowicie: etatowi, stali i pracownicy w służbie przygotowawczej oraz pracownicy nawiązujący stosunek pracy, wymienieni w rozporządzeniu Ministra Obrony Narodowej z 22 marca 1945 roku o powołaniu do wojskowej służby komunikacji na kolejach. Praktyka jednak nie była już tak oczywista, jak można by sądzić na podstawie analizy tych aktów prawnych, ponieważ oprócz wymienionych kategorii zatrudnionych pojawili się

43 Rozporządzenie Ministra Obrony Narodowej z 22 marca 1945 r. o powołaniu do wojskowej służby komunikacji na kolejach, Dz.U. R.P. $1945 \mathrm{nr}$ 11, poz. 62.

44 Do tej kategorii zaliczono: publiczno- i prywatnoprawnych pracowników przedsiębiorstwa PKP, Francusko-Polskiego Towarzystwa Kolejowego, kolei prywatnych pod zarządem PKP lub prywatnych, z wyłączeniem niewykwalifikowanych robotników sezonowych, zatrudnionych przy sezonowych robotach drogowych i innych, trwających krócej niż 6 miesięcy w roku.

45 Do tej kategorii zaliczono: byłych pracowników Kolei Wschodniej lub niemieckich kolei państwowych i prywatnych na okupowanych terenach Polski, z wyłączeniem niewykwalifikowanych pracowników, zatrudnionych dorywczo wyłącznie przy sezonowych robotach drogowych, naładunku lub wyładunku materiałów oraz pracowników, którzy na Kolei Wschodniej lub na kolejach niemieckich na okupowanym terenie Polski zostali zemerytowani lub zwolnieni ze służby.

${ }^{46}$ Do tej kategorii zaliczono osoby: mające ukończone studia wyższe $\mathrm{z}$ uwzględnieniem potrzeb służby komunikacji na kolejach, specjalne wydziały kolejowe w szkołach zawodowych, kursy fachowe kolejowe albo takie, które pracowały bez względu na upływ czasu, w przedsiębiorstwach spedycyjnych, fabrykach lub zakładach mechanicznych albo elektrotechnicznych pracujących dla kolei. 
nowi pracownicy, tak zwani szarwarkowi oraz sezonowi. Statut prawny tych pracowników regulował dokument Naczelnej Prokuratury Wojskowej, skierowany do wojskowego Prokuratora $\mathrm{PKP}^{47}$. W dokumencie tym, podpisanym przez gen. brygady Aleksandra Tarnowskiego, wyjaśniono, że za zmobilizowanych uważa się nie tylko stale zatrudnionych pracowników, lecz także pracowników tymczasowych, zarówno w czasie faktycznego zatrudnienia, jak i od chwili wezwania do pracy. Bez znaczenia było zatem to, czy wezwanie do pracy zostało wystawione przez władzę administracyjną czy też inną. Podstawę prawną takiego stanowiska tworzył dekret o mobilizacji, w którym na pierwszym miejscu stawiano za cel właściwe funkcjonowanie kolei w czasie wojny i pokoju, w celach wojskowych i gospodarczych. Sezonowi pracownicy mieli odpowiadać za przestępstwa popełnione w okresie, na który zostali przyjęci do pracy, względnie w czasie faktycznego wykonywania pracy aż do zwolnienia $\mathrm{z}$ niej. $Z$ kolei osoby przydzielone do przejściowych prac na PKP, celem wykonywania obowiązku szarwarkowego, należało uznać za zmobilizowane na okres wyznaczony do pracy, bez względu na to, czy do pracy stawili się, czy uchylali się od jej wykonania. Ze względu na charakter przejściowy pracy robotników szarwarkowych byli oni zmobilizowani tylko na okres wyznaczonych prac na rzecz PKP, jednak ze względu na ów przejściowy charakter ich obowiązku z jednej strony i ważność oraz konieczność punktualnego wykonania prac na rzecz PKP z drugiej strony kolejowy wymiar sprawiedliwości miał przede wszystkim, w sprawach mniejszej wagi, stosować wojskowe przepisy dyscyplinarne, obowiązujące na PKP, a normujące uprawnienia przełożonych kolejowych i wojskowego prokuratora PKP.

Ten szeroki zakres właściwości sądów i ekspozytur prokuratury w stosunku do pracowników PKP został częściowo ograniczony rozporządzeniem Rady Ministrów z 2 listopada 1945 roku o służbie w przedsiębiorstwie „Polskie Koleje Państwowe". Rozporządzenie to wprowadziło w miejsce odpowiedzialności karnej odpowiedzialność służbową osób zmobilizowanych do służby w komunikacji kolejowej za przestępstwa przewidziane w art. 128 (niewykonanie rozkazu) i art. 115 (samowolne opuszczenie stanowiska służbowego) kodeksu karnego WP z 1944 roku.

Wobec braku stosownych aktów wykonawczych do dekretu o militaryzacji Polskich Kolei Państwowych sędziowie i prokuratorzy opracowali projekty tymczasowych przepisów dyscyplinarnych jako poniekąd samowolne, acz wymuszone sytuacją uzupełnienie przepisów prawa karnego materialnego. Na podstawie rozkazu Naczelnego Dowódcy WP nr 142 z 18 grudnia 1944 roku wojskowe przepisy dyscyplinarne weszły w życie do użytku służbowego. Rozkaz ten został 15 stycznia 1945 roku uzupełniony o zarządzenia Ministra Komunikacji — W sprawie odpowiedzialności pracowników PKP za naruszenie dyscypliny

47 IPN BU 894/11 Naczelna Prokuratura Wojskowa w Warszawie, Rozkazy personalne władz zwierzchnich. Etat OSW/15, Tajny dokument gen. A. Tarnowskiego do Wojskowego Prokuratora PKP z dnia 6 kwietnia 1945 r., k. 131. 
pracy i W sprawie składania doniesień karnych — a także instrukcję W sprawie przetrzymywania na odwachach kolejowych pracowników PKP ukaranych dyscyplinarnie $^{48}$. W przepisach dyscyplinarnych kary dyscyplinarne były wymierzane między innymi za przewinienia przeciwko karności, porządkowi i przepisom służbowym, niezawierającym cech przestępstwa oraz za przestępstwa pospolite i wojskowe w przypadkach umorzenia postępowania przez uprawnione organy wojskowej służby sprawiedliwości ze względu na niecelowość ścigania w trybie karnym.

W wyniku militaryzacji PKP spora grupa osób cywilnych znalazła się pod zwierzchnictwem wojskowego wymiary sprawiedliwości, co spowodowało gwałtowne pogorszenie ich sytuacji. Dlatego od chwili wprowadzenia militaryzacji zawodowe związki kolejowe i sami kolejarze walczyli o zmianę swojego stanu, ponieważ byli świadomi tego, w jak niekorzystnej sytuacji się znaleźli. Mimo że kolejowy wymiar sprawiedliwości nie działał sprawnie, często poprzestając jedynie na karach mało represyjnych w stosunku do kolejarzy, uważali oni, że zostali objęci bardzo represyjnym systemem. Ze względu na liczne niedociągnięcia, niedopatrzenia czy zwyczajne zaniechania kolejarze w rzeczywistości nie odczuwali represyjności kolejowego wymiaru sprawiedliwości jako szczególnie dotkliwego, jednak należy podkreślić, że w sprawach jednostkowych czasami ten specyficzny wymiar sprawiedliwości potrafił być brutalny w stosunku do podległych.

\section{Bibliografia}

\section{Monografie i artykuły naukowe}

Dzieje kolei w Polsce, red. D. Keller, Rybnik 2012.

Dziowgo J., $W$ walce z przestępczościa w kolejnictwie, „Wojskowy Przegląd Prawniczy” 1946, nr 1. Jarosiński J., Wspótpraca sądu i prokuratury wojskowej ze Zwiazkiem Zawodowym Pracowników Kolejowych w latach 1944-1949, „Wojskowy Przegląd Prawniczy” 1982, nr 1.

Jasiak K., W majestacie „ludowego prawa”. Skazani przez „wymiar sprawiedliwości” w Lodzi w latach 1945-1956, „Kultura i Historia” 2004, nr 7.

Kochański A., Polska 1944-1991. Informator historyczny, t. 1. Podziat administracyjny, ważniejsze akty prawne, decyzje i enuncjacje państwowe (1944-1956), Warszawa 1996.

Miętek A., Materiały źródlowe obrazujące działalność sądów wojskowych Ludowego Wojska Polskiego w okresie wojny 1943-1945, „Biuletyn Wojskowej Służby Archiwalnej” 1971, nr 3.

Nazarewicz J., Działalność legislacyjna państwa ludowego w zakresie prawnej jego ochrony w latach 1944-1945, „Wojskowy Przegląd Prawniczy” 1979, nr 2.

Nazarewicz J., Udziat Prokuratury wojskowej w ochronie ludowo-demokratycznego ustroju w Polsce w latach 1944-1955, „Wojskowy Przegląd Prawniczy” 1983, nr 3.

Ostafiński-Bodler R., Sąy wojskowe w Polskich Siłach Zbrojnych i ich kompetencje w sprawach karnych 1914-2002, Toruń 2002.

48 E. Romanowska, Wojskowe Prokuratury..., s. 115. 
Prokopowicz J., Rola Prokuratury Wojskowej PKP w zakresie uruchomienia i usprawnienia kolejnictwa, „Wojskowy Przegląd Prawniczy” 1945, nr 3.

Romanowska E., Karzace ramię sprawiedliwości ludowej. Prokuratury wojskowe w Polsce w latach 1944-1955, Warszawa 2012.

Romanowska E., Wojskowe Prokuratury Polskich Kolei Państwowych w latach 1944-1949 formalno-prawne podstawy działalności, ,Przegląd Historyczno-Wojskowy” 12, 2011, nr 1 (234).

Rzepliński A., Przystosowanie ustroju sadownictwa do potrzeb państwa totalitarnego w Polsce w latach 1944-1956, [w:] Przestęstwa sędziów i prokuratorów w Polsce lat 1944-1956, red. W. Kulesza, A. Rzepliński, Warszawa 2000.

Szwagrzyk K., Prawnicy czasu bezprawia. Sędziowie i prokuratorzy wojskowi w Polsce 1944-1956, Kraków-Wrocław 2005.

Tkaczew W., Powstanie i działalność organów Informacji Wojska Polskiego w latach 1943-1948, Warszawa 1994.

Wesołowski A., W cieniu wojny i polityki. Sadownictwo Wojska Polskiego na froncie wschodnim w latach 1943-1945, Torun 2003.

Zaborski M., Oni skazywali na śmierć...Szkolenie sędziów wojskowych w Polsce $w$ latach 19441956, [w:] Skryte oblicze systemu komunistycznego. U źródet zła, red. R. Bäcker, P. Hübner, Warszawa 1997.

Zaborski M., Ustrój sądów wojskowych w Polsce w latach 1944-1955, Lublin 2005.

Zamkowska S., Odbudowa i funkcjonowanie kolei polskich 1944-1949, Warszawa 1984.

Żurawicki S., Tendencje prawodawcze demokracji ludowej, „Wojskowy Przegląd Prawniczy” 1946, nr 2-3.

\section{Akty prawne}

Dekret PKWN z 23 września 1944 roku Prawo o ustroju Sądów Wojskowych i Prokuratury Wojskowej, Dz.U. R.P. 1944 nr 6, poz. 29.

Dekret PKWN z 30 października 1944 roku O ochronie państwa, Dz.U. R.P. 1944 nr 10, poz. 50.

Dekret PKWN z 4 listopada 1944 roku o militaryzacji Polskich Kolei Państwowych, Dz.U. R.P. $1944 \mathrm{nr} 11$, poz. 55.

Rozporządzenie Ministra Obrony Narodowej z 22 marca 1945 roku o powołaniu do wojskowej służby komunikacji na kolejach, Dz.U. R.P. 1945 nr 11, poz. 62.

Rozporządzenie Rady Ministrów z 2 listopada 1945 o służbie w przedsiębiorstwie „Polskie Koleje Państwowe”, Dz.U. R.P. 1945 nr 52, poz. 299.

Ustawa z 27 marca 1920 roku o kolejach w czasie wojny, Dz.U. R.P. 1920 nr 27, poz. 160.

Ustawa z 30 marca 1939 roku o komunikacjach w służbie obrony Państwa, Dz.U. R.P. 1939 nr 29, poz. 195.

Ustawa z 15 sierpnia 1944 roku o tymczasowym trybie wydawania dekretów z mocą ustawy, Dz.U. R.P. $1944 \mathrm{nr}$ 1, poz. 3.

Źródła archiwalne

IPN BU 807/653; 929/63/653 Naczelna Prokuratura Wojskowa w Warszawie. Sprawozdania statystyczne Ekspozytury PKP Wrocław.

IPN BU 894/11 Naczelna Prokuratura Wojskowa w Warszawie, Rozkazy personalne władz zwierzchnich.

IPN BU 894/86, Naczelna Prokuratura Wojskowa w Warszawie. Sprawozdanie WP PKP — opisowe z działalności i statystyczne o przestępczości.

IPN BU 894/130 Naczelna Prokuratura Wojskowa w Warszawie. 